\title{
Marine Natural Products As Anticancer Agents
}

\author{
Priyankashukla ,Xiaoqiu xiao \\ Chongqing Medical University, Chongqing , China
}

\begin{abstract}
The marine environment remain an important source of compounds that possess anticancer activities and some other demonstrated activities likeantitumor, immunomodulation, anti-inflammatory, allergy, analgesia. The purpose of this article is to present different different compounds of anticancer agent which are derived from marine sources and present their structured part and different mode of action of all these different drugs. The drugs which are included in this article, some of them are in pre-clinical trials or clinical development and some are available in market such as Cytarabine and ET-743.
\end{abstract}

Marine natural products-

\section{Introduction}

These are the compounds which are derived from marine organisms. There are different number of compounds that are derived from marine organisms by deep-sea collection and aquaculture technology.

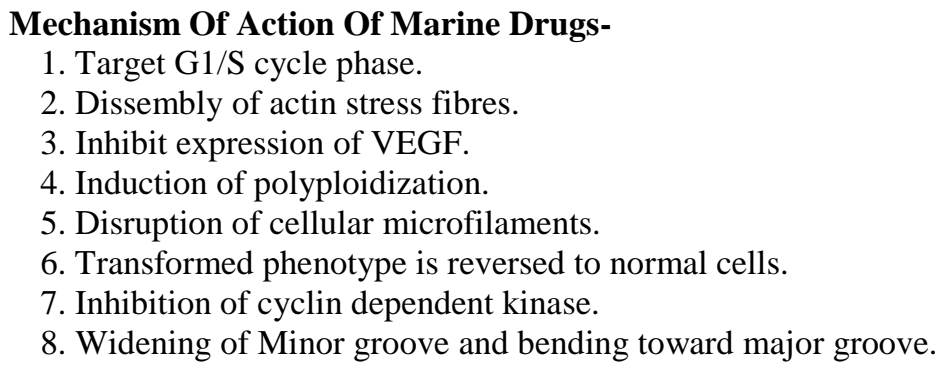

Plant based anticancer agents-

Plants are very popular which are used in the treatment of cancer and about $60 \%$ natural sources are used as anticancer agents. The natural drugs which plays a very important part in cancer treatment are Vinca alkaloids- vincristine, vinblastine. Taxens- paclitaxel, docetaxel. Podophyllotoxin- etoposide, teniposide.Camptothecin- topothecan.Anthracyclines- doxorubicin, daunorubicin. Vinca alkaloid was a potent compound in prevention of leukemias and non-hodgkin's diseases. Podophyllum exhibit their activity in smallcell lung carcinoma. Etoposide is a Topoisomerase 2 inhibitor, it is a stabilizing enzyme and it lead to break the DNA. Taxanes also show anti-tumor activity against ovarian and breast cancer. Camptothecin show anti-tumor activity against colorectal and ovarian cancer. Vincristine inhibits microtubule assembly.

Following are the compounds that are still in clinical practice.

\begin{tabular}{|l|l|l|l|}
\hline SERIAL NO. & COMPOUND & USES & STATUS \\
\hline 1$)$ & Vincristine & $\begin{array}{l}\text { Lymphoma, Leukemia, breast, } \\
\text { lung. }\end{array}$ & Phase-3 \& 4 \\
\hline 2$)$ & Vinblastine & Breast, lymphoma, renal cancer. & Phase 3\& 4 \\
\hline 3$)$ & Paclitaxel & $\begin{array}{l}\text { Ovary, breast, lung, head and } \\
\text { neck cancer. }\end{array}$ & Phase 3 \& 4. \\
\hline 4$)$ & Docetaxel & Breast and lung cancer. & Phase 3 \\
\hline 5$)$ & Topotecan & $\begin{array}{l}\text { Ovarian, lung and pediatric } \\
\text { cancer. }\end{array}$ & Phase 2 \& 3 \\
\hline
\end{tabular}

Following are the plants which are used as anticancer agents.

\begin{tabular}{|l|l|l|l|}
\hline SERIAL NO. & PLANT SPECIES & FAMILY & PLANT PART \\
\hline 1$)$ & Salvia officinalis & Labiate & Leaves \\
\hline 2$)$ & Viscus album & Loranthaceae & Leaves \\
\hline 3$)$ & Croton draco & Eubhorbiaceae & Aerial part \\
\hline 4$)$ & Piper latifolium & Piperaceae & Leaf \\
\hline 5$)$ & Pinusparviflora & Pinaceae & Strobilus \\
\hline 6$)$ & Thevetiagaumeri & Apocynaceae & Leaf and stem \\
\hline 7$)$ & Juncusacutus & Juncaceae & Leaf \\
\hline 8$)$ & Carapaguianensis & Meliaceae & Seed oil \\
\hline 9$)$ & Croton lechleri & Euphorbiaceae & Latex \\
\hline 10$)$ & Thapsiagarganica & Apiaceae & Fruit \\
\hline
\end{tabular}




\section{Marine Natural Products}

These are the compounds which are derived from marine organisms. There are different number of compounds that are derived from marine organisms by deep-sea collection and aquaculture technology.

- CYTARABINE (Isolated from Cryptothecacrypta)

CYTARABINE is currently used in treatment of leukemia and lymphoma patients and important thing is that cytarabine is the first marine derived anticancer agent.

- GEMCITABINE

It is fluorinated derivatives of Cytarabine. It is approved for-

- $\quad$ breast cancer

- Bladder cancer

- Pancreatic cancer

- Non-small cell lung cancer

Following are those compounds that have entered in clinical evaluation-

- DIDEMNIN B (Isolated from tunicate Trididemnum sodium)

In 2001, It shows good antitumour activity for both human tumour as well as in athymic mice. But later, after all information of Didemnin like treatment protocol and treatments of many cancer, the compound exerts too toxic and due to this it was terminated by NCI.

- APLIDINE (Isolated from Aplidiumalbicans)

It exerts high anticancer activity during preclinical studies. As comparatively with Didemnin B, Aplidine appears more active.

During clinical trials phase-1 of Aplidine-

It shows antitumour activity with different solid tumours like renal cell carcinoma, malignant melanoma, tumours of neuroendocrine origin.Toxic effects are also observed by Aplidine- Myalgia, disturbance of liver function, nausea, vomiting, local irritation at injection site.

Clinical trial phase-2 of Aplidine for anticancer activity will start in future.

- Ecteinascidin (Isolated from Ecteinascidia turbinate).

It is also known as Trabectedin and Yondelis. It is first marine derived anticancer agent approved in European union for the treatment of soft tissue sarcoma and also for ovarian cancer. It exerts good anticancer activity in murine and human tumour cell line. Ecteinascidin-743 is selected for clinical trials out of many ecteinascidin.

During clinical trials phase-1 of Ecteinascidin-It was approved for breast cancer, melanoma, ovarian cancer.

During clinical trial phase-2 of Ecteinascidin-

This compound was confirm for the treatment of soft tissue sarcoma and breast cancer. Toxic effects are also observed by Ecteinascidin-

Fatigue, emesis, panocytopenia, transaminitis, neutropenia.

Mechanism of action of Ecteinascidin is modification of DNA by guanine specific alkylation at N2 position.

- DOLASTATIN (Isolated from Dolabellaauricularia)

Dolastatin 10 was selected for clinical trials. During clinical trials phase-1 and 2of Dolastatin- it was approved for solid tumour but no anticancer activity seen. Toxic effects are also observed by DolastatinLocal irritation at injection site and mild peripheral neuropathy.

- BRYOSTATIN-1 (Isolated from Buglaneritina)

It promotes the activity of protein kinase $\mathrm{c}$ but lacks the tumour promoting activity. It also has immunomodulatory effects. During clinical trials phase 1 and 2 of Bryostatin-1, It shows antitumour activity in patients with malignant melanoma, lymphoma, ovarian carcinoma. And finally it shows no antitumour activity in patients of solid tumours and lung cancer during clinical trials phase 1 and 2. It also stimulate some other biological activities which involve- immune system modulation, induction of cell differentiation, radioprotection, it also exert synergistic interaction with other anticancer agents such as Ara-C, Dolastatin, prednisone, Tamoxifen, Vincristine, Doxorubicin. Toxic effects are also observed by Bryostatin-

Myalgia, local phlebitis, fatigue, nausea, vomiting and thrombocytopenia.

- DEPSIPEPTIDE (Isolated from Chromobacteriumviolaceum)

It shows cytotoxicity activity in various human solid tumour cell line. It act as inhibitor of a histone deacetylase. Clinical trials of Depsipeptide will begin soon.

In UNITED STATES, we have 3 FDA approved marine derived drugs-

- Cytarabine

- Vidarabine

- Ziconotide 


\section{- CYTARABINE (Isolated from Cryptothecacrypta)}

Cytarabine is also known as arabinosyl cytosine or Ara-C. Cytarabine is an S-phase specific antimetabolite cytotoxic agent and it convert cytosine arabinoside into cytosine arabinoside triphosphate and it compete with physiologic substrate deoxycitidine triphosphate and it results in inhibition of DNA polymerase and inhibition of DNA synthesis. Cytarabine currently available in 2 forms-

\section{- Conventional Cytarabine}

- Liposomal formulations

- Conventional Cytarabine is indicated for acute lymphocytic leukemia, acute meningeal leukemia.

- Liposomal Cytarabine is indicated for intrathecal treatment of lymphomatous meningitis.

- VIDARABINE (Isolated from Cryptothecacrypta)

Vidarabine also known as adenine arabinoside, Ara-A. Adenine arabinoside is converted into adenine arabinoside triphosphate which inhibit viral DNA polymerase and DNA synthesis of herpes, vaccinia. Marketing status of Vidarabine by USFDA-

Conventional Vidarabine is used for treatment of acute keratoconjuctivitis, recurrent epithelial keratitis caused by herpes simplex virus type- $1 \& 2$.

- ZICONOTIDE (Isolated from venom of fish hunting marine snail conus magus).

Ziconotide is synthetic form of w-conotoxin. It was the first drug which is approved by USFDA. Trade name of ZICONOTIDE is Prialt. It has poor tissue penetration when it administered systemically. And also some hypotensive effects. So due to this it was administered by continous infusion by external or implanted pump. It shows good analgesic action with a novel mechanism of action. Ziconotide reversibly block Ntype calcium channel. In 2004, it received FDA approval for the treatment of chronic pain with cancer or AIDS.

- DISCODERMOLIDE (Isolated from Discodermia dissolute)

It was used as new immunosuppressive and also cytotoxin. In 1996, a discovery confirms that Discodermolide bound to microtubules more potently than Taxol.

Discodermolide induces $\mathrm{G} 2 / \mathrm{m}$ phase cell cycle arrest in lymphoid and non-lymphoid cells.

- KAHALALIDE F (Isolated from Elysiarufescens)

In 1990, it entered in preclinical testing but its mechanism of action had not fully determined. It was suggested for the treatment of tumour cells with high lysosomal activity such as prostate tumours. In 2000, it entered in clinical trial phase-1 in Europe for the treatment of androgen independent prostate cancer. In 2003 it entered in clinical trial phase-2 for the treatment of prostate cancers. This compound is specific for lysosomal compartments in cells. It is suggested for prostate cancer and breast cancer cell lines.

- $\quad$ SPISULOSINE (Isolated from Spisulapolynima)

This compound is currently in clinical trials phase -1 for treatment of solid tumours.

It mainly promotes disassembly of actin stress fibres.

- HTI-286(HEMIASTERLINE DERIVATIVE) (Isolated from Hemiasterella minor)

It induces inhibition of cell proliferation and increase in polynuclear cells.

- $\quad$ KRN-7000 (Isolated from Agelasmauritianus)

This compound is suggested for antitumour and immunostimulatory activities.

In 2001, it entered in clinical trials phase-1 in Europe for cancer immunotherapy.

- ARAGUSTEROL (Isolated from Xestospongia species)

It is a broad spectrum growth inhibitory activity. It also shows high anticancer activity. After all over study of Aragusterol, investigators understood that it target the G1 phase of cell cycle by downregulatingcyclin dependent kinases and G1 cyclins and block the entry of human tumour cells into S-phase.

- ASCIDIDEMIN (Isolated from Cytodytesdellechiajei)

It was shown to be a potent inducer of apoptosis in both human and murine leukemia cells. It cause oxidative demage to DNA and it also exerts DNA cleaving activity.

\section{AGENTS that are now withdrawn from antitumour clinical trials-}

- DIDEMNIN B (Isolated from tunicate Trididemnum sodium)

In 2001, It shows good antitumour activity for both human tumour as well as in Athymic mice. But later, after all information of $\mathrm{D}$ idemin like treatment protocol And treatments of many cancer, the compound exerts too toxic and due to this, It was determind by NCI.

- DOLASTATIN (Isolated from Dolabellaauricularia) 
Dolastatin 10 was selected for clinical trials. During clinical trials phase-1 and 2of Dolastatin- it was approved for solid tumour but no anticancer activity seen. Toxic effects are also observed by DolastatinLocal irritation at injection site and mild peripheral neuropathy.

- GIROLLINE (Isolated from Pseudaxinyssacantharella)

During clinical trial phase-1, Girolline was succeed in man but it shows hypertensive effects on treated patients so due to this trial were stopped.

- BENGAMIDE

Bengamide $\mathrm{A}$ is used in this for clinical trial. This derivative shows inhibitor of methionine aminopeptidases and then it entered in clinical trial phase-1 in 2000 but it was withdrawn in middle of 2002.

- CRYPTOPHYCIN (isolated from a Lichen)

This compound shows only antifungal activity but it was too toxic also so thats why it was not procced.

Following are the compound that are used as anticancer agents-

\begin{tabular}{|c|c|c|c|c|c|}
\hline $\begin{array}{l}\text { SERIAL } \\
\text { NO. }\end{array}$ & COMPOUND & ORGANISM & CHEMISTRY & $\begin{array}{l}\text { EXPERIMENTAL } \\
\text { MODEL }\end{array}$ & $\begin{array}{l}\text { MECHANISM } \\
\text { ACTION }\end{array}$ \\
\hline 1) & Argusterol & Sponge & steroid & $\begin{array}{l}\text { Human and murine } \\
\text { cancer cell line }\end{array}$ & $\begin{array}{l}\text { Target the G1/S cell cycle } \\
\text { phase. }\end{array}$ \\
\hline 2) & Ascididemin & Tunicate & Alkaloid & $\begin{array}{l}\text { Human and murine } \\
\text { leukemia cell lines }\end{array}$ & $\begin{array}{l}\text { Induction of apoptosis, no } \\
\text { effect on topoisomerase } 1 \\
\& 2 \text {. }\end{array}$ \\
\hline 3) & Ascididemin & Tunicate & Alkaloid & $\begin{array}{l}\text { Murine leukemia cell } \\
\text { line }\end{array}$ & Reductive DNA cleavage. \\
\hline 4) & Bryostatin-1 & Bryozooa & Macrolide & $\begin{array}{l}\text { Human lymphoma cell } \\
\text { line }\end{array}$ & $\begin{array}{l}\text { Sensitizes cells to radiation } \\
\text { mediated antiproliferation. }\end{array}$ \\
\hline 5) & Bryostatin-1 & Bryozooa & Macrolide & $\begin{array}{l}\text { Murine invivotumour } \\
\text { model }\end{array}$ & $\begin{array}{l}\text { Paclitaxel-bryostatin } \\
\text { combination is sequence } \\
\text { dependent. }\end{array}$ \\
\hline 6) & Bryostatin-1 & Bryozooa & Macrolide & $\begin{array}{llr}\text { Murine } & \text { in } & \text { vivo } \\
\text { xenograft } & \text { model } & \text { for } \\
\text { diffuse large } & \text { cell } \\
\text { lymphoma. } & \end{array}$ & $\begin{array}{l}\text { It enhances } \text { CHOP } \\
\text { regimen for diffuse large } \\
\text { cell lymphoma. }\end{array}$ \\
\hline 7) & Cryptophycin & Bacteria & Depsipeptide & Bovine brain tubulin & $\begin{array}{l}\text { Noncovalent binding to a } \\
\text { tubulin high affinity site. }\end{array}$ \\
\hline 8) & Cryptophycin & Bacteria & Depsipeptide & $\begin{array}{l}\text { Murine in vivo } \\
\text { xenograft model }\end{array}$ & $\begin{array}{l}\text { Effective in combination } \\
\text { with } \\
\text { paclitaxel and } \\
\text { flurouracil. }\end{array}$ \\
\hline 9) & Cryptophycin & Bacteria & Depsipeptide & $\begin{array}{l}\text { Murine in vivo } \\
\text { xenograft models }\end{array}$ & $\begin{array}{l}\text { Effective in a number of } \\
\text { clinical } \\
\text { regimens. }\end{array}$ \\
\hline 10) & Didemnin B & Tunicate & Depsipeptide & $\begin{array}{l}\text { Human } \\
\text { adenocarcinoma cell } \\
\text { line. }\end{array}$ & $\begin{array}{l}\text { Intact depsipeptide ring } \\
\text { required for protein } \\
\text { synthesis inhibition. }\end{array}$ \\
\hline 11) & Discodermolide & Sponge & Polyketide & $\begin{array}{l}\text { Human and murine } \\
\text { tumour cell line }\end{array}$ & $\begin{array}{l}\text { Apoptosis as a potential } \\
\text { mechanism of synergy } \\
\text { with paclitaxel. }\end{array}$ \\
\hline 12) & Ecteinascidin-743 & Tunicate & Isoquinoline & $\begin{array}{l}\text { Human colon } \\
\text { carcinoma }\end{array}$ & $\begin{array}{lr}\text { Inhibition of } & \text { human } P \\
\text { glycoprotein } & \text { gene } \\
\text { transcription. } & \end{array}$ \\
\hline 13) & Ecteinascidin-743 & Tunicate & Isoquinoline & $\begin{array}{l}\text { Transfected NIH } 3 \mathrm{~T} 3 \\
\text { fibroblast }\end{array}$ & $\begin{array}{l}\text { Promoter specific } \\
\text { transcription interference }\end{array}$ \\
\hline 14) & Ecteinascidin-743 & Tunicate & Isoquinoline & Molecular dynamics & $\begin{array}{l}\text { Minor groove bending } \\
\text { towards major groove and } \\
\text { protein DNA interaction. }\end{array}$ \\
\hline 15) & $\begin{array}{l}\text { Eleutherobin } \\
\text { analogues }\end{array}$ & Coral & $\begin{array}{l}\text { Diterpene } \\
\text { glycoside }\end{array}$ & $\begin{array}{l}\text { Human breast } \\
\text { carcinoma cell line }\end{array}$ & $\begin{array}{l}\text { Eleuthrobinpharmacophore } \\
\mathrm{B} \text { region necessary for } \\
\text { tubulin binding. }\end{array}$ \\
\hline 16) & $\begin{array}{l}\text { Eleuthrobin } \\
\text { analogues }\end{array}$ & Coral & Diterpene & $\begin{array}{l}\text { Human breast } \\
\text { carcinoma cell line }\end{array}$ & $\begin{array}{l}\text { Enhanced antimitotic } \\
\text { activity. }\end{array}$ \\
\hline 17) & Fascaplysin & Sponge & Alkaloid & $\begin{array}{lr}\text { Human } & \text { colon } \\
\text { carcinoma and } & \text { arcoma cell line and } \\
\text { sarcomal fibroblast. } & \\
\text { normal }\end{array}$ & $\begin{array}{l}\text { Cyclin dependent kinase } 4 \\
\text { inhibition. }\end{array}$ \\
\hline 18) & Jaspamide & Sponge & Depsipeptide & $\begin{array}{l}\text { Human promyelocytic } \\
\text { leukemia cell line. }\end{array}$ & $\begin{array}{l}\text { Induction } \\
\text { polyploidization. }\end{array}$ \\
\hline 19) & Spisulosine & Clam & $\begin{array}{l}\text { Alkyl } \\
\text { alcohol }\end{array}$ & $\begin{array}{l}\text { Monkey fibroblast cell } \\
\text { lines. }\end{array}$ & $\begin{array}{l}\text { Disassembly of actin stress } \\
\text { fibres. }\end{array}$ \\
\hline
\end{tabular}




\section{Future Prospects}

The combination of new structural compounds with novel mechanism of action and translates into new methods to treat cancer and by which we can improve the results for patients. Marine natural compounds exerts as important sources of new drugs and lead structures. The aquaculture of source organisms including sponges, tunicates will supply new drug products and will progress in cancer applications.

\section{References}

[1]. Rinehart KL. Antitumor compounds from tunicates. Med Res Rev,2000;20: 1-27.

[2]. Geldof AA, Mastbergen SC, Henrar REC, Faircloth GT. Cytotoxicity and neurocytoxicity of new marine anticancer agents evaluated using in vitro assays. Cancer ChemotherPharmacol. 1999;44:312-18.

[3]. Raymond E, Ady-Vago N, Ribrag V, et al. Phase1 and pharmacokinetic study of aplidine, a marine derived compound, given as a $24 \mathrm{~h}$ infusion every 2 weeks in patients with advanced solid tumors and non-Hodgkin's lymphoma. Ann Oncol. 2000; 11:134.

[4]. Izquierdo MA, Bowman A, Martinez M, et al. A phase 1 study of aplidine, a marine derived compound, given as a $1 \mathrm{~h}$ infusion weekly X 3 in advanced solid tumors and non-Hodgkin's lymphomas. Ann Oncol 2000; 11:134.

[5]. Garcia-Rocha M, Garcia- Gravalos MD, Avila J. Characterisation of antimitotic products from marine organisms that disorganise the microtubule network. Br J Cancer 1996; 42:2493-97.

[6]. Zewails-foote M, Hurley LH. Ecteinascidin 743-a minor groove alkylator that bends DNA towards the minor groove. J Med Chem 1999;42:2493-97.

[7]. Demetri G, Garcia- carbonero, Harmon D, et al. Ecteinascidin-743 induces objective responses and disease control in patients with advanced non-osseous sarcomas. Ann Oncol 2000;11:126.

[8]. Le Cesne A, Judson I, Radford J, et al, Phase 2 study of ET-743 in advanced soft tissue sarcoma in adults. Ann Oncol 2000;11:126.

[9]. Wright JJ, Blatner G, Cheson BD. Clinical trials referral resource. Clinical trials of dolastatin-10. Oncology 1993;3:68-70.

[10]. Pitot HC, McElroy EA, Reid JM, et al. Phase 1 trial of dolastatin-10 in patients with advanced solid tumors. Clin Cancer Res 1999;5:525-31.

[11]. Krug LM, Miller VA, Kalemkerian GP, et al. Phase 2 study of dolastatin-10 in patients with advancedvnon-small cell lung cancer. Ann Oncol 2000;11:227-28

[12]. TrennG,et al. immunomodulating properties of a novel series of protein kinase $\mathrm{C}$ activators. The bryostatins. $\mathrm{J}$ Immunol 1988;140:433-39.

[13]. Hornung RL, et al. Preclinical evaluation of bryostatin as an anticancer agent several murine tumor cell lines: in vitro and in vivo activity. Cancer Res 1992;52:101-07.

[14]. Prendiville J, et al. A phase1 study of intravenous Bryostatin 1 in patients with advanced cancer. Br J Cancer 1993;68:418-24.

[15]. E.tenHarr, et al. Discodermolide, a cytotoxic marine agent that stabilizes microtubules more potently than taxol. Biochem 1996;35:243-50.

[16]. Kan Y, Fujita T, Sakamoto B, et al. A new cyclic depsipeptide from the Hawaiian green alga bryopsis species. J Nat Prod 1999;62:1169-72.

[17]. Newman, D.J. et al. Therapeutic agents from the sea: Biodiversity, chemo- evolutionary insight and advances to the end of Darwin's $200^{\text {th }}$ year. Diving Hyperb. Med. 2009;39:216-25.

[18]. Thomas X.Chemotherapy of acute leukemia in adults. Expert Opin. Pharmacother. 2009;10:221-237.

[19]. Absalon, M.J.et al. Treatment strategies for pediatric acute myeloid leukemia. Expert Opin. Pharmacother 2009;10:57-59.

[20]. Olivera, B.M. w-Conotoxin MV11A from marine snail venom to analgesic drug. In Drugs from the Sea 2000;75-85.

[21]. Bingham, J.P. et al. Drugs from slugs - Past, present and future perspectives of omega- conotoxin research. Chemo Biol. Interact 2010;183:1-18.

[22]. Kerr, L.M and Yoshikami,D. A venom peptide with a novel presynaptic blocking action. Nature1984;308:282-284

[23]. Milijanich, G.P. Ziconotide -neuronal calcium channel blocker for treating severe chronic pain. Curr. Med. Chem.2004;11:3029-40.

[24]. Mcgivern, J.G. Targetting N-type and T-type calcium channels for the treatment of pain. Drug Discov. Today 2006;11:245-53.

[25]. Rauck, R.L. et al. IntrathecalZiconotide for neuropathic pain- a review. Pain Pract. 2009;9:327-37.

[26]. Verweij, J. Soft tissue sarcoma trials-one size no longer fits all. J. clin. Oncol.2009;27:3085-87.

[27]. Yap, T.A. et al. Beyond chemotherapy-targeted the raiesd in ovarian cancer. Nat. Rev. Cancer 2009;9:167-81.

[28]. Jackson, K. et al. The Halichondrins and E7389. Chem. Rev. 2009;109:3044-79.

[29]. Erba, E.et al. Et-743, a natural marine compound, with a unique mechanism of action. Eur. J. Cancer 2001;37:97-105

[30]. Tan, A. R. et al. Phase 1 study of eribulinmesyate administered once every 21 days in patients with advanced solid tumors. Clin. Cancer Res. 2009; 15:4213-19. 